\title{
Polymorphic variants (p.Ser141Ser and p.Arg737Gly) at the NAGLU gene are really indicative of pseudodeficiency alleles?
}

\author{
Diana Rojas Malaga ${ }^{1,2}$, Sandra Leistner-Segal ${ }^{1,3^{*}}$ and Ana Carolina Brusius-Facchin ${ }^{1,3}$
}

\begin{abstract}
Filocamo et al. recently published a paper describing the presence of a pseudodeficiency allele, constituted by $\mathrm{p}$. Ser141Ser and p.Arg737Gly polymorphisms at the NAGLU gene, which leads to a reduced level of the alpha-Nacetyl-D-glucosaminidase activity. Based on analysis performed in Brazilian patients, using a customized gene panel containing SGSH, NAGLU, HGSNAT and GNS we observed that p.Ser141Ser (rs659497) and p.Arg737Gly (rs86312) variants were present in homozygosis in all of our MPS IIIB patients and in the majority of MPS IIIA, IIIC and IIID patients, and there was no significant decrease of the alpha-N-acetyl-D-glucosaminidase enzyme activity in this group when compared with those without the "pseudodeficiency allele". Thus, we suggest that these two variants are not producing a pseudodeficiency allele.
\end{abstract}

Keywords: NAGLU gene, Alpha-N-acetyl-D-glucosaminidase, Pseudodeficiency allele, Sanfilippo B syndrome

\section{To the Editor}

We read with great interest the article by Filocamo et al. [1] in the November 2018 issue of Italian Journal of Pediatrics. In this manuscript, the authors mention that a complication for molecular analysis of NAGLU gene (associated with Sanfilippo B syndrome or also called mucopolysaccharidoses type IIIB) is the presence of a pseudodeficiency allele, constituted by p.Ser141Ser and p.Arg737Gly polymorphisms simultaneously, which leads to a reduced level of the alpha-N-acetyl-D-iglucosamnidase activity.

We have been working on the diagnosis of mucopolysaccharidoses (MPS) over the past 35 years, and during this time, MPS diagnosis was confirmed in 1184 Brazilian patients, of which, 192 were affected by one of the four subtypes of MPS III [2]. As part of our MPS III investigation, after detection of heparan sulphate glycosaminoglycan in urine, we performed different enzyme activity assays in leukocytes

\footnotetext{
* Correspondence: ssegal@hcpa.edu.br

${ }^{1}$ Medical Genetics Service, Hospital de Clínicas de Porto Alegre (HCPA), Rua Ramiro Barcelos 2350, Porto Alegre, RS 90035-903, Brazil

${ }^{3}$ Postgraduate Program in Medicine: Medical Science, Universidade Federal do Rio Grande do Sul (UFRGS), Rua Ramiro Barcelos 2400, Porto Alegre, RS 90035-003, Brazil

Full list of author information is available at the end of the article
}

in order to reach the definitive diagnosis and to determine the MPS III subtype [2]. Following this step, approximately $40 \%$ of our MPS III patients, were analyzed by targeted-next generation sequencing (NGS), using a customized gene panel containing SGSH, NAGLU, HGSNAT and GNS which was designed to simultaneous sequence the entire coding regions plus $20 \mathrm{pb}$ of intron-exon junction of these genes. Pathogenic variants were detected in all the cases. Therefore, we have extensive biochemical and molecular data of our group of patients.

Based in our data, p.Ser141Ser (rs659497) and p.Arg7 37Gly (rs86312) variants were present in homozygosis in all our MPS IIIB patients analyzed by NGS. For these patients, the enzyme activities were below the reference range, as they are clinically affected by MPS IIIB as proven by mutation analysis.

On the other hand, we have patients with other types of MPS III (IIIA, IIIC and IIID) where the same alterations that are said to cause the pseudodeficiency allele were present in homozygosis. These variants were detected because patients had clinical phenotype of MPS III and were analyzed in the same NGS panel used for the 4 types of MPS III. For those, the NAGLU enzyme

(c) The Author(s). 2019 Open Access This article is distributed under the terms of the Creative Commons Attribution 4.0 International License (http://creativecommons.org/licenses/by/4.0/), which permits unrestricted use, distribution, and reproduction in any medium, provided you give appropriate credit to the original author(s) and the source, provide a link to the Creative Commons license, and indicate if changes were made. The Creative Commons Public Domain Dedication waiver (http://creativecommons.org/publicdomain/zero/1.0/) applies to the data made available in this article, unless otherwise stated. 
Table 1 Genotype and alpha-N-acetyl-D-glucosaminidase activity for MPS III patients

\begin{tabular}{lllll}
\hline & $n$ & $\begin{array}{l}\text { p.Ser141Ser } \\
(c .423 T>C)\end{array}$ & $\begin{array}{l}\text { p.Arg737Gly } \\
(c .2209 C>G)\end{array}$ & $\begin{array}{l}\text { alpha-N-acetyl-D-glucosaminidase activity in leukocytes } \\
\text { (reference value: 10-34 nmol/17 h/mg protein) }\end{array}$ \\
\hline MPS IIIB patients & 12 & $\mathrm{C} / \mathrm{C}$ & $\mathrm{G} / \mathrm{G}$ & $0,25 \pm 0,17$ \\
Other MPS III patients & 18 & $\mathrm{C} / \mathrm{C}$ & $\mathrm{G} / \mathrm{G}$ & $14,5 \pm 3,5$ \\
& 2 & $\mathrm{C} / \mathrm{C}$ & $\mathrm{C} / \mathrm{G}$ & $19,8 \pm 3,2$ \\
& 2 & T/C & $\mathrm{C} / \mathrm{G}$ & $16,5 \pm 1,5$ \\
\hline
\end{tabular}

activity was within the normal range when compared to normal controls as shown in Table 1.

These two variants were also present in homozygosis in one MPSIIIA patient from Turkey and two MPS IIIB from Ecuador.

For our group of MPS III patients, allele frequencies of p.Ser141Ser and p.Ar737Gly were 0.9706 and 0.9412 , respectively. In addition, Exome Aggregation Consortium (ExAC) reported that frequency for p.Ser141Ser is 0.9947 and 0.9055 for p.Arg737Gly [3]. Furthermore a Brazilian mutation database (ABraOM), which comprised the exomic variants of a cohort of 609 healthy Brazilian elderly, reported 602 homozygotes for p.Ser141Ser (0.9942) and 459 homozygotes for p.Arg737Gly (0.8686) [4].

Pseudodeficiency alleles are not rare in Lysosomal Disorders, including several MPS disorders [5-10], nevertheless the high frequency of both polymorphisms in worldwide populations and the fact that the presence of these alleles does not alter the MPS IIIB enzyme activity when present, suggests that these two variants are not producing a pseudodeficiency allele. Thus, no false positive results and no alteration on the protein product or changes in gene expression are detected in the presence of these two variants.

\section{Abbreviations}

ExAC: Exome Aggregation Consortium; GNS: N-acetylglucosamine-6-sulfatase; HGSNAT: Heparan-Alpha-Glucosaminide N-Acetyltransferase;

MPS: Mucopolysaccharidoses; NAGLU: Alpha-N-acetyl-D-glucosaminidase;

NGS: Next Generation Sequencing; SGSH: N-sulphoglucosamine

sulphohydrolase

\section{Acknowledgements}

Not applicable.

\section{Funding}

This study was partially supported by FIPE-HCPA (grant \# 2013-0254) and Brazilian Institute for Population Medical Genetics (INAGEMP).

DRM is supported by CAPES post-doc scholarship. SLS receives a Research Grant from CNPq.

\section{Availability of data and materials}

Data sharing is not applicable to this article as no datasets were generated or analysed during the current study.

\section{Authors' contributions}

DRM and ACBF carried out the molecular genetic studies and participated in the sequence alignment and NGS interpretation. ACBF, DRM and SLS were responsible for epidemiological and statistical analysis. DRM was responsible for drafting the manuscript. SLS conceived of the study, and participated in its design and coordination and helped to draft the manuscript. All authors read and approved the final manuscript.
Ethics approval and consent to participate

This study was approved by the institutional ethics committee of Hospital de Clínicas de Porto Alegre, Brazil which is recognized by the Office for Human Research Protections as an Institutional Review Board (IRB0000921). All patients provided written informed consent (protocol number 2003-0066).

Consent for publication

Not applicable.

\section{Competing interests}

The authors declare that they have no competing interests.

\section{Publisher's Note}

Springer Nature remains neutral with regard to jurisdictional claims in published maps and institutional affiliations.

\section{Author details}

${ }^{1}$ Medical Genetics Service, Hospital de Clínicas de Porto Alegre (HCPA), Rua Ramiro Barcelos 2350, Porto Alegre, RS 90035-903, Brazil. ${ }^{2}$ Postgraduate Program of Genetics and Molecular Biology, Universidade Federal do Rio Grande do Sul (UFRGS), Av. Bento Gonçalves 9500, Porto Alegre, RS 91501-970, Brazil. ${ }^{3}$ Postgraduate Program in Medicine: Medical Science, Universidade Federal do Rio Grande do Sul (UFRGS), Rua Ramiro Barcelos 2400, Porto Alegre, RS 90035-003, Brazil.

Received: 3 January 2019 Accepted: 5 May 2019

Published online: 14 May 2019

\section{References}

1. Filocamo M, Tomanin R, Bertola F, Morrone A. Biochemical and molecular analysis in mucopolysaccharidoses: what a paediatrician must know. Ital J Pediatr. 2018;44(S2):129 Available from: http://www.ncbi.nlm.nih.gov/ pubmed/30442161. [cited 2019 Mar 7].

2. Giugliani R, Federhen A, Michelin-Tirelli K, Riegel M, Burin M. Relative frequency and estimated minimal frequency of lysosomal storage diseases in Brazil: report from a reference laboratory. Genet Mol Biol. 2017;40(1):31-9 Available from: http://www.ncbi.nlm.nih.gov/pubmed/28304074. [cited 2018 May 22].

3. Lek M, Karczewski K, Minikel EV, Samocha KE, Banks E, Fennell T, et al. Analysis of protein-coding genetic variation in 60,706 humans. Nature. 2016; 536(7616):285-91 Available from: http://www.nature.com/articles/ nature19057. [cited 2018 Dec 12].

4. Naslavsky MS, Yamamoto GL, de Almeida TF, Ezquina SAM, Sunaga DY, Pho $\mathrm{N}$, et al. Exomic variants of an elderly cohort of Brazilians in the ABraOM database. Hum Mutat. 2017;38(7):751-63 Available from: http://doi.wiley. com/10.1002/humu.23220. [cited 2018 Jun 22].

5. Ricketts MH, Goldman D, Long JC, Manowitz P. Arylsulfatase a pseudodeficiency-associated mutations: population studies and identification of a novel haplotype. Am J Med Genet. 1996;67(4):387-92 Available from: http://www.ncbi.nlm.nih.gov/pubmed/8837707. [cited 2018 Jun 11].

6. Aronovich EL, Pan D, Whitley CB. Molecular genetic defect underlying al pha- Liduronidase pseudodeficiency. Am J Hum Genet. 1996;58(1):75-85 Available from: http://www.ncbi.nlm.nih.gov/pubmed/8554071. [cited 2018 Jun 11].

7. Gort L, Santamaria R, Grinberg D, Vilageliu L, Chabás A. Identification of a novel pseudodeficiency allele in the GLB1 gene in a carrier of GM1 gangliosidosis. Clin Genet. 2007;72(2):109-11 Available from: http://doi.wiley. com/10.1111/j.1399-0004.2007.00843.x. [cited 2018 Jun 11].

8. Chabas A, Giros ML, Guardiola A. Low beta-glucuronidase activity in a healthy member of a family with mucopolysaccharidosis VII. J Inherit Metab 
Dis. 1991;14(6):908-14 Available from: http://www.ncbi.nIm.nih.gov/ pubmed/1779649. [cited 2018 Jun 11].

9. Sandberg S, Deanching M, Hoganson G, Wenger D, Whitley C. Pseudodeficiency allele of the $\mathrm{N}$-acetylgalactosamine-4-sulfatase gene identified in a family with Maroteaux-Lamy syndrome (mucopolysaccharidosis type VI). Mol Genet Metab. 2008;93(2):34 Available from: http://linkinghub.elsevier. com/retrieve/pii/S1096719207005343. [cited 2018 Jun 26].

10. Vervoort R, Islam MR, Sly W, Chabas A, Wevers R, de Jong J, et al. A pseudodeficiency allele (D152N) of the human beta-glucuronidase gene. Am J Hum Genet. 1995;57(4):798-804 Available from: http://www.ncbi.nlm. nih.gov/pubmed/7573038. [cited 2018 Jun 26].

Ready to submit your research? Choose BMC and benefit from:

- fast, convenient online submission

- thorough peer review by experienced researchers in your field

- rapid publication on acceptance

- support for research data, including large and complex data types

- gold Open Access which fosters wider collaboration and increased citations

- maximum visibility for your research: over $100 \mathrm{M}$ website views per year

At $\mathrm{BMC}$, research is always in progress.

Learn more biomedcentral.com/submissions 